\title{
Does Downsizing Strategy affect the Retained Employees Performance?
}

\author{
Robert Kinanga and Anne Cherono Cheruiyot
}

Maasai Mara University, Narok, Kenya

Correspondence should be addressed to: Robert Kinanga; rongeta@yahoo.com

Received date: 19 September 2014; Accepted date: 5 July 2015; Published date: 22 December 2015

Academic Editor: Noura Abd El Maksoud Abdallah Eissa

Copyright (C) 2015. Robert Kinanga and Anne Cherono Cheruiyot .Distributed under Creative Commons CC-BY 4.0

\begin{abstract}
Reduction of employees has become a potentially valuable way of securing a competitive advantage and improving organizational performance, downsizing has been in existence for a while now however, its effect on employee or organizational performance has brought mixed reactions in both developed and developing countries. This quagmire has led to a lot of uncertainty while considering downsizing as a tool of enhancing employee performance. Therefore, this study sought to find out the effect reduction of employees as a downsizing strategy on performance of employees of Barclays bank hypothesized as there is no relationship between reduction of employees and employee performance. The study adopted a survey research design. Data for the study were collected from a sample 183 employees of Barclays Bank South Rift Hub, Kenya. Questionnaires were used as the sole data collection instrument. The data that was collected from the field was analyzed using both descriptive and inferential statistics. The findings established that there was a strong positive correlation of 0.982 between reduction of employees and the dependent variable employee performance. The results indicated that higher levels of effective employee reduction leads to effective performance of commercial banks hence they need to consider applying downsizing. The results of this study shall therefore benefit the management of commercial banks to understand the effects of downsizing and put in place appropriate strategies to ensure that only the positive effects leading to improved performance are emphasized.
\end{abstract}

Keywords: Downsizing, Employee Performance, Barclays Bank

\section{Introduction}

In many companies, a lot of effort goes into separation packages and support for the employees who are leaving the organization as a result of downsizing with very little or even no attention given to the employees who are remaining. However, it is argued that what creates a high level of distrust in organizations is that leaders fail to acknowledge the impact of restructuring and downsizing on the people who are staying. This paper therefore aimed at finding out the effect of reduction of employees as a downsizing strategy on the performance of employees. It was guided by research objective which was to examine how reduction of employees 
during downsizing affects the performance of the employees of the Bank and the hypothesis that there is no relationship between reduction of employees and employee performance.

\section{Related Studies}

In the book by Bloise, Cook \& Hunsaker, 2003, restructuring has been a major trend in developing countries as most companies have undergone restructuring with the aim of improving the organizations' effectiveness and efficiency, hence improving profits in the organisation. According to Kang (1999) downsizing began as the strategy of sickly corporations shedding workers in the face of weak demand, but soon strong firms looking to boost shareholder value even further adopted the policy. Downsizing is the conscious use of permanent personnel reductions in an attempt to improve efficiency and effectiveness of the organisation. Downsizing is regarded by management as one of the preferred routes to turning around declining organizations, cutting costs, and improving organizational performance most often as a cost-cutting measure. Vrooman, 2009 noted that the labour market is more flexible, and employers can more easily respond than in the past to reduced demand for their products or services by lying off employees

According to Greenberg \& Baron, (2000), downsizing is likely to lead to disruptions in the workplace. Greenberg \& Baron also noted that many companies consider the organization's profits by cutting down costs with all the attention firmly fixed on the need for change, the leaders are often blind to the impact of downsizing on people and their relationships and hence on the performance of the people. Greenberg \& Baron, (2000), further noted that organizations focus more on taking care of the people who are leaving rather than those who are remaining. In many companies, a lot of effort goes into separation packages and support for the employees who are leaving the organization as a result of downsizing with very little or even no attention given to the employees who are remaining. Winkler,
2002 on the other hand noted that what creates a high level of distrust in organizations is that leaders fail to acknowledge the impact of restructuring and downsizing on the people who are staying.

According to Cappelli (2000) "Downsizing" is a term that was introduced to describe the contemporary development of permanent job cuts motivated by an effort to improve operating efficiency, not necessarily because of declines in business. Downsizing has received a great deal of attention, especially in the business press, in part because it appears to represent something of an enigma. Baumol s, Blinder and Worlf (2003) in his study on American firms found out that since the 1980's through the present time, around ten million jobs have been eliminated in the U.S. Munoz-Bullon and Sanchez-Bueno (2008) also noted that despite the growth of downsizing, the practice has been prominent in developed countries such as United States. Chen et al., (2001), identified that the practice of downsizing has recently become relevant in other contexts such as Canada, Japan, or Korea, the controversy surrounding its benefits still persists. This is due to the fact that downsizing eliminates redundancies and reduces employment costs, many executives believe that this practice helps firms to compete efficiently and improve profitability. Cascio (2003) indicate that, the objective of downsizing is to improve the organizational efficiency, productivity and/or competitiveness. The works by Espahbodi, R, T, A, John, G, Vasudevan, 2000; and Chen et al. (2001) show that profitability of American firms improved subsequently due to downsizing announcements. Likewise, empirical evidence in other countries supports the same conclusion according to the findings of Yu and Park, (2006) on Korean firms.

This study rests on the idea that the effects of job insecurity on performance are neither purely negative nor purely positive. Instead, job insecurity is both a hindrance and a challenge stressor. Job insecurity can be perceived as a stressful discrepancy between what employees hope for (job 
security) and what employers offer (job insecurity) that leads to effort withdrawal and thus to a reduction of job performance. At the same (but to a lesser degree), job insecurity can also motivate people to increase the effort because high performance might be perceived as a safeguard against being laid off. Both effects are captured by our integrated model that was supported by our data. Consequently, managers who believe that increasing job insecurity is a feasible motivation strategy should be warned not to overlook that the effects of job insecurity are predominantly negative.

De Meuse et al., (2004) and Yu and Park, (2006) on the other hand, have noted that, downsizing may not result in improved profitability of firms. According to the two studies, it is noted that downsizing is not enough to influence the performance of an organization. It is noted that though the reduction of staff can slim down a firm, it doesn't necessarily make it healthier and hence profitable. Munoz-Bullon and Sanchez-Bueno (2008) support this conclusion that employee reduction does not necessarily have a positive impact on organizational performance. According to Munoz-Bullon and Sanchez-Bueno a study carried out in the United States found that downsizing practices carried out along the 1980s and early 1990s were unable to reflect corporate profitability. In another related study Cascio (2003) found that companies which had implemented downsizing between 1981 and 1990 did not enjoy larger financial performance. In an extension of this research it was noted that since 2000 downsizers enjoyed lower profitability than stable employers or upsize in the two years subsequent to the announcement of layoffs. Other studies on American corporations also showed that downsizing did not lead to improved financial performance (De Meuse et al, 2004). It was further noted that financial performance of companies which downsized did not significantly differ from non-downsizers. Similarly, found that downsizing was not associated with better corporate performance among Canadian firms.
Djordjevic (2007) considered the effects of downsizing on establishment performance; the analyses from this study are broadly consistent with the common-sense view that job cuts make more sense when establishments experience excess capacity than when they do not. Even in such situations, however, the benefits of improvements in sales per employee must overcome increases in labor costs per employee. Djordjevic (2007) looked at downsizing as job cuts when operating at or above capacity, appears to hurt sales per employee. In the context of this model, it is clearer why downsizing may hurt performance, because it is difficult to cut without doing damage to organizational capabilities when there is no slack to cut. In most cases, labor costs per employee move in the opposite direction from changes in sales per employee: When job cuts make sales per employee rise, so do labor costs per employee, and when the former fall, so do the latter. This relationship may mitigate some of the gains from cutting employees as well as the losses and lead to an overall moderating effect in relations with performance outcomes.

An explanation for these findings is that downsizing may not be managed effectively. Indeed, learning how to downsize effectively is important not only for companies experiencing difficulties, but also as a proactive strategy for healthy organizations. Djordjevic (2007) further noted that embarking on downsizing without learning how to do it well leads to several kinds of problems. The loss of vital organizational memory is one of the negative and expensive effects firms have suffered in downsizing. If managers do not think and plan ahead, their companies risk losing key skills and experiences as well as valuable knowledge when employees are moved out of their working units or leave the organization entirely.

Cappelli (2000) in his study on examining the incidence of downsizing and its effect on the establishment performance, noted that academic research and casual observation before the early 1980s suggested that employment levels, and reductions in jobs, were derived in a 
straightforward way from the demand for a firm's product or services. Cappelli further noted that most layoffs were seen as driven by business cycles; they were temporary in that employees were rehired when product demand returned, and they concentrated on production workers. The exceptions were typically limited to industry-specific market changes; the long-term decline of an industry, such as coal mining, or the movement of industries overseas, such as textiles. Virtually all of the public policy attention given to unemployment centered on the view that job losses are driven by cyclical or structural declines in product demand.

Goesaerty and Heinzz, (2012), studied downsizing and firm performance, considering the banking industry in early 2005 , the bank reported highest profits for years after the downsizing was done. With downsizing, the company reorganizes its structure by undertaking 6,400 layoffs in order to achieve higher profitability in the future. In the same period, another company 'Opel' announced a record loss and decided to shed 12,000 jobs to decrease their production capacities and to rescue the company. Both CEOs stated that there was no alternative to the downsizing. These two firms faced a different financial situation, but shared one common goal: to increase their performance through downsizing. The fact that these two firms recorded higher profits after downsizing may assist the current study in establishing whether the case is similar in organizations operating in Kenya.

According to Cappelli (2000) it is noted that despite the popular attention given to downsizing and the continuing stream of studies about job security for individual workers, there has been essentially no research directed at the causes of downsizing. A growing body of research on the consequences of downsizing developed to address the perception that firms could improve their financial performance by downsizing. Although Cappelli's study does not relate to the central question being addressed in the current study, the study may shed light on how to conceptualize and measure downsizing. Cappellis study established that financial performance was measured by stock prices seems to decline following downsizing. A similar view was held by Gunderson, Verma, and Verma (1997) who studied the effect of downsizing among Canadian firms, in this study it was noted that at least some in some cases downsizing was noted to have a negative performance of the firms as a result of the adverse effects on the workforce.

Ahmadjian and Robinson, (2001) noted that downsizing has a negative effect where by in their study they reported that it can foster an organization so preoccupied with bean counting, so anxious about where the ax will fall next, that employees become narrow minded, self-absorbed, and risk averse. It was noted that the ability of employees to continue to work well is likely to be severely curtailed in such stressful situations and they tend to be even less able to innovate and learn. Therefore, the most significant conclusion drawn by studies of experiences in U.S. corporations is that downsizing must be regarded as something firms have to actively learn how to do well. Instead of conceiving downsizing to be "a one-time, quick-fix solution” (De Meuse et al., 2004).), a comprehensive framework is required, a whole process of grappling with the underlying problems and developing a range of activities to both restructure the organization and enable employees to make the transition to different jobs within or outside the organization (Greenberg, J. \& Baron, R.A. (2000).

\section{Research Methodology}

The study adopted a descriptive survey. This design was most suitable because it provides appropriate basis for descriptive analysis of characteristics of a sample from the population (Mugenda and Mugenda, 2008). The target population of the study included all the employees of Barclays Bank of Kenya, South Rift Hub. The study used stratified, simple random and purposive sampling techniques in selection of the sample. Stratified sampling technique was used to select the six branches from within the South Rift Hub while simple random sampling technique 
was used to select the employees from each of the selected branches. Purposive sampling was used to select all employees from the management level who included area managers, accessible branch managers, the accessible operations managers and the sales managers. The researcher used the sample size formula according to Bartlett, Kotrlik, \& Higgins (2001) was to determine the sample for the study. The researcher used a sample size of 183 employees from the South Rift Hub of Barclays Bank that were accessible at the time of the study. Of which 17 were managers at the management level while the rest 166 were from the middle level employees. This represented a total percentage of $52.2 \%$ which is above the sample of above $20 \%$ as recommended (Mugenda and Mugenda, 2003). Data was collected using a questionnaire; the method was selected because the sample population is literate.

The data was analyzed using both descriptive and inferential statistics, descriptive statistics, frequencies and percentages were used to give summary of the results. Inferential statistics where correlation and regression were used in order to establish-the relationship between the dependent variable and the independent variable as described in the objectives.

\section{Research Findings and Discussions}

The respondents were asked to indicate their opinion on the following questions related to employee reduction and their effect on employee performance as stipulated in table 4.1 below.

\section{Table 4.1: Respondents Opinion on Reduction of Employees as Downsizing Strategy}

To what extent do you agree with the following statements on the change in job roles on employee performance (mark on a scale of 1-5) 1- Strongly Agree, 2- Agree 3- Not Sure, 4Disagree, 5- Strongly Disagree

\begin{tabular}{|c|c|c|c|c|c|c|}
\hline & & 1 & 2 & 3 & 4 & 5 \\
\hline 1 & $\begin{array}{l}\text { The organization recognizes the } \\
\text { need of relationship among its staff. }\end{array}$ & $\begin{array}{c}9 \\
(7.14 \%)\end{array}$ & $\begin{array}{c}100 \\
(85.7 \%)\end{array}$ & $\begin{array}{c}8 \\
(7.1 \%)\end{array}$ & $\begin{array}{c}0 \\
(0 \%)\end{array}$ & $\begin{array}{c}0 \\
(0 \%)\end{array}$ \\
\hline 2 & $\begin{array}{l}\text { Reduction of employees leads to } \\
\text { fear and job insecurity }\end{array}$ & $\begin{array}{c}83 \\
(71.4 \%) \\
\end{array}$ & $\begin{array}{c}17 \\
(14.2 \%)\end{array}$ & $\begin{array}{c}17 \\
(14.2 \%)\end{array}$ & $\begin{array}{c}0 \\
(0 \%)\end{array}$ & $\begin{array}{c}0 \\
(0 \%)\end{array}$ \\
\hline 3 & $\begin{array}{l}\text { Reduction of employees in the bank } \\
\text { leads to negative public image. }\end{array}$ & $\begin{array}{c}25 \\
(21.4 \%) \\
\end{array}$ & $\begin{array}{c}59 \\
(50 \%)\end{array}$ & $\begin{array}{c}17 \\
(14.2 \%) \\
\end{array}$ & $\begin{array}{c}8 \\
(7.1 \%) \\
\end{array}$ & $\begin{array}{c}8 \\
(7.1 \%) \\
\end{array}$ \\
\hline 4 & $\begin{array}{l}\text { Reduction of employees increases } \\
\text { employee workload }\end{array}$ & $\begin{array}{c}109 \\
(92.9)\end{array}$ & $\begin{array}{c}8 \\
(7.1 \%)\end{array}$ & $\begin{array}{c}0 \\
(0 \%)\end{array}$ & $\begin{array}{c}0 \\
(0 \%)\end{array}$ & $\begin{array}{c}0 \\
(0 \%)\end{array}$ \\
\hline 5 & $\begin{array}{l}\text { Reduction of employees reduces the } \\
\text { efficiency and effectiveness of the } \\
\text { remaining employees in the } \\
\text { organisation }\end{array}$ & $\begin{array}{c}33 \\
(28.6)\end{array}$ & $\begin{array}{c}25 \\
(21.4)\end{array}$ & $\begin{array}{c}8 \\
(7.1 \%)\end{array}$ & $\begin{array}{c}50 \\
(42.9 \%)\end{array}$ & $\begin{array}{c}0 \\
(0 \%)\end{array}$ \\
\hline 6 & $\begin{array}{l}\text { Reduction of employees improves } \\
\text { the financial validity of the } \\
\text { organisation. }\end{array}$ & $\begin{array}{c}91 \\
(78.2 \%)\end{array}$ & $\begin{array}{c}17 \\
(14.2 \%)\end{array}$ & $\begin{array}{c}8 \\
(7.1)\end{array}$ & $\begin{array}{c}0 \\
(0 \%)\end{array}$ & $\begin{array}{c}0 \\
(0 \%)\end{array}$ \\
\hline 7 & $\begin{array}{l}\text { Reduction of employees improves } \\
\text { the customer satisfaction in the } \\
\text { organisation }\end{array}$ & $\begin{array}{c}17 \\
(14.2 \%)\end{array}$ & $\begin{array}{c}25 \\
(21.4 \%)\end{array}$ & $\begin{array}{c}75 \\
(64.3 \%)\end{array}$ & $\begin{array}{c}0 \\
(0 \%)\end{array}$ & $0(0 \%)$ \\
\hline
\end{tabular}


The study sought to recognize the relationship existing among its staff during reduction of employees so as to enhance performance,8(7.1\%) strongly agree while the remaining $8(7.1 \%)$ employees were not sure. On whether Reduction of employees leads to fear and job insecurity $83(71.4 \%)$ of the employees strongly agreed, $17(14.2 \%)$ agreed that Reduction of employees leads to fear and job insecurity and the remaining $17(14.2 \%)$ were not sure. On whether Reduction of employees in the bank leads to negative public image only $25(21.4 \%)$ agreed to this statement, $59(50 \%)$ agreed, on the other hand $17(14.2 \%)$ of the respondents were note sure, $8(7.1 \%)$ respondents disagree, the remaining $8(7.1 \%)$ emloyees strongly disagreed.

Majority of the respondents 109(92.9) of employees in BBK South Rift Hub strongly agreed to the statement Reduction of employees increases employee workload, the remaining $8(7.1 \%)$ agreed. On whether Reduction of employees reduces the efficiency and effectiveness of the remaining employees in the organisation a majority of the respondents $50(42.9 \%)$ of employees in BBK South Rift Hub disagreed to this statement, another 33(28.6) strongly agreed to the very statement 25(21.4) agreed and the remaining $8(7.1 \%)$ were not sure.

On whether Reduction of employees improves the financial validity of the organisation, a majority of $91(78.2 \%)$ of the employees of BBK South Rift Hub strongly agreed to the statement,another $17(14.2 \%)$ agreed to the stament, while the remaining8(7.1)were not sure of the same statement. Finally on whether Reduction of employees improves the customer satisfaction in the organisation, $17(14.2 \%)$ strongly agreed to the statement, majority of $75(64.3 \%)$ of the respondents were not sure, while the remaining $25(21.4 \%)$ agreed.

In regard to correlation analysis the results shows that using Pearson's correlation coefficient there was a strong positive relationship $r=0.960$, which was highly significant at $\mathrm{p}$ value $=0.000$ between the reduction of employees and the performance during the downsizing exercise in the organization. On the basis of these results the study establishes that similar results existed from other scholars who considered whether reduction of employees and the performance of employees though they studied different organizations. Chen et al., (2001) for instance it was noted that if the survivors in any change leading to employee reduction don't believe that it was legitimate, their commitment to the organization may get adversely impacted. But if they believed that the change was going to be beneficial to them then their performance will not be affected. Similarly Cascio (2002) and Spreitzer \& Mishra, (2002) indicated that the way employees perceive the reduction whether it is fair or not will have a strong influence on their performance to the organization in a downsizing context

Regression analysis indicated that there is no linear relationship between reduction of employees and employee performance. In testing whether there is a relationship between the reduction of employees and employees' performance and the effect of the relationship. The result shows that there is a positive and significant relationship between reduction of employees and the employee's performance during the downsizing process in the organization. The results revealed that the Pearson's correlation coefficient $\mathrm{R}=0.96$ which is positive and indicating a very strong correlation and highly significant $\mathrm{p}$ value $=0.000$ between reduction of employees and the employee's performance. This indicates that the effect of downsizing on the performance of the employees at Barclays bank can be explained by $92.2 \%$ of reduction of employees.

\section{Conclusion and Recommendations}

Throughout the study, majority of the respondents agreed with the statement; the organization recognizes the need of relationship among its staff in its reduction 
of employees so as to enhance performance. Majority of the employees strongly agreed that reduction of employees leads to fear and to job insecurity and only a slight majority agreed that reduction of employees in the bank leads to negative public image.On the other hand majority of the respondent employees in BBK South Rift Hub strongly agreed to the statement Reduction of employees increases employee workload.

However, Majority of the respondent employees in BBK South Rift Hub disagreed on whether Reduction of employees reduces the efficiency and effectiveness of the remaining employees . a majority of the employees of BBK South Rift Hub. strongly agreed that reduction of employees improves the financial validity of the organisation. Finally, majority of BBK employees South Rift Hub were not sure on whether Reduction of employees improves the customer satisfaction in the organisation.

The study findings appear to agree with scholars who are in support of the positive effects of reduction of employees since if it is properly undertaken the employees who remain behind tend to be more effective and efficient in their duties, this translates to better organisational performance.

The study therefore recommends proper structuring of the process of reduction of employees as a downsizing strategy. In addition since Reduction of Employees is a key process in employee Performance the ratio of employees to the workload should be equal so as to maximize the available revenue with the best possible skills, hence maximum output.

The study recommends that the same study should be duplicated to cover a wider area, not just the South Rift Hub and establish whether similar results can be established. There is need to have further study to compare the performance of the different hubs in BBK in line with the effects of downsizing on the performance of employees cited in this study.

\section{References}

1. Ahmadjian, C. L. And P. Robinson (2001). "Safety in Numbers: Downsizing And The Deinstitutionalization of Permanent Employment In Japan." Administrative Science Quarterly 46: 622654.

2. Armstrong, M. (1999). Human Resources Management Practice. London: Kogan Press Ltd.

3. Bartlett, J.E.; Kotrlik, J.W.; Higgins, C.C. (2001). Organizational Research: Determining Appropriate Sample Size In Survey Research. Information Technology, Learning and Performance Journal, 19:4350.Causes, And Consequences, New York, NY: Russell Sage Foundation Press

4. Baumol, J.W., Blinder, S.A. And Wolff, N.E. (2003). Downsizing In America: Reality.

5. Bloisi, W., Cook, C.W. \& Hunsaker, P.L. (2003). Management And Organisational Behaviour. London: Mcgraw-Hill.

6. Cascio, W. F. (2002). Strategies for Responsible Restructuring. Academy of Management Executive, 16(3): 80-91.

7. Cascio, W.F. (2002). Responsible Restructuring: Creative and Profitable Alternatives To Layoffs. San Francisco: Berrett-Koehler.

8. De Meuse K.P., Bergmann T.J., Vanderheiden P.A. and Roraff C.E (2004). New Evidence Regarding Organizational Downsizing and a Firm's Financial Performance: A Long Term Analysis, Journal of Managerial Issues 16 (2), 155177 (2004).

9. Djordjevic B.:( 2007)."Managing Human Resource during Downsizing Process", Doctoral Thesis, The Economic Faculty of Belgrade.

10.Espahbodi, R.T, John A., Vasudevan G (2000).The Effects of Downsizing on Operating Performance. Rev. Quant. Finance Accounting (15) pp. 107-126. 
11.G. Yu And J. Park (2006). The Effect of Downsizing on the Financial Performance and Employee Productivity of Korean Firms. International Journal of Manpower, 27 (3), 230-250.

12.Greenberg, J. \& Baron, R.A. (2000). Behavior in Organisations: Understanding And Managing The Human Side Of Work. 7th Edition. New Jersey: Prentice Hall.

13.Gyu Chang Yu, Jong Sung Park, (2006). "The Effect of Downsizing on the Financial Performance and Employee Productivity of Korean Firms", International Journal of Manpower, Vol. 27 Issue: 3, Pp.230 - 250
14.Mishra, K., Spreitzer, G., \& Mishra, A. (2002). Preserving Employee Morale during Downsizing. Sloan Management Review, 39, 83-95.

15.Mugenda And Mugenda (1999). Research Methods Qualitative and Quantitative Approach. Nairobi. Act Press

16. Mugenda O.M and Mugenda A.G (2003). Research Methods: Qualitative and Quantitative Techniques, Nairobi Act Press.

17.Peter Cappelli \& Neumark, David (2000). On The Job: Is Long-Term Employment a Thing of The Past? New York: Russell Sage. 